\title{
Converting Agricultural Land To Mining From The Perspective Of Islamic Economic Law
}

\section{Alfiandi Zikra}

Sekolah Tinggi Ilmu Tarbiyah Bustanul arifin, Aceh, Indonesia

Corresponding Author: alfianzikra070@gmail.com

\section{ABSTRACT}

\begin{abstract}
The conversion of agricultural land to non-agricultural functions has become a phenomenon in almost all regions. With the aim of increasing the economy instantly and quickly One thing that may not be taken into consideration in carrying out land conversion is the impact arising from the conversion of land functions, both in terms of the declining agricultural output sector or environmental damage due to the transfer of functions. One of the conversions of agricultural land to mining occurred in Pangkalan Jambu District, Merangin Regency, Jambi Province. The data analysis method of this research is descriptive. The findings of this study are: First, in the process of converting agricultural land into mining in Pangkalan Jambu District, Merangin Regency, Jambi Province, the majority of people still use manual tools, Second, the conversion of agricultural land into mining in Pangkalan Jambu District, Merangin Regency, Jambi Province has a significant impact on community economic improvement. However, the impact of environmental damage is much greater. Third, in the study of Islamic economic law, the conversion of agricultural land to mining in Pangkalan Jambu District, Merangin Regency, Jambi Province violates the concept of maslahah.
\end{abstract}

Keywords

Land Conversion, Community Economics, Islamic Economic Law

\section{INTRODUCTION}

The conversion of agricultural land to non-agricultural functions has become a phenomenon in almost all regions. With the aim of increasing the economy instantly and quickly One thing that may not be taken into consideration in carrying out land conversion is the impact that arises from the land use change, both in terms of the declining agricultural output sector or environmental damage due to the transfer of function, plus the state of Indonesia is a country with a staple food of rice originating from rice which is one of the agricultural sectors in Indonesia (Fauzi, 2010). Indonesia is an agricultural country where the majority of the population consumes rice produced by the rice plant. The increasing population of Indonesia is also a challenge in itself to meet the national food needs. Rice plays an important role in Indonesia because it is the main source of carbohydrates for food other than corn, sago, and tubers that are consumed by most of the Indonesian population (Supriadi, 2010). Judging 
from this aspect, the transfer of mining agricultural land has two impacts, namely positive impacts and negative impacts, with the transfer of these functions having a positive impact on the community's economy which is increasingly promising. increasing number of people with non-agricultural activities. Meanwhile, the negative impact is in the form of damage to agricultural land, the environment and waters in the area so that it is vulnerable to triggering flooding, and making the river water unfit for consumption.

In Arabic the term economics is expressed by the word al-'iqtisad, which literally means simplicity and frugality. Economics is knowledge about events and issues related to human efforts individually (personally), groups (family, ethnic groups, organizations) in meeting unlimited needs faced with limited resources (Elias, 2005). The word al-iqtisad (economics) in the Qur'an is only mentioned three times, namely in the form of isim fa'il, muqtasid and muqtasidah. In this definition there are two main things that form the legal basis of the Islamic economic system, namely: the Qur'an and the Sunnah of the Prophet, the laws taken from the two basic foundations are conceptually and in principle fixed (cannot change anytime and anywhere). , but in practice for certain things and situations and conditions may apply marunnah and some are subject to change (Fikri, 1997).

The leading Neo-Classical economist, Lord Robbins, also objected to limiting the subject matter of economics by saying that the objective of discussing economics was the positive aspect of material welfare. Therefore, he proposes another understanding that the core of economic activity is the aspect of "choice in the use of resources" (Rahrdjo, 1999). The research objectives to be achieved are to explain the practice of converting agricultural land to mining and describe the impact of converting agricultural land to mining on the community's economy as well as explaining the conversion of agricultural land to mining from an Islamic economic perspective in Pangkalan Jambu District, Merangin Regency, Jambi Province.

\section{RESEARCH METHODS}

This study uses a qualitative method, because the problems to be studied are not clear, holistic, complex, dynamic and full of meaning. In this study, researchers went directly to the field to conduct interviews with the community, and the government in Pangkalan Jambu District, Merangin Regency, Jambi Province in order to obtain data related to the conversion of agricultural land to mining and the impact of community welfare carried out in Pangkalan Jambu District, Merangin Jambi Regency. There are four kinds of data collection 
techniques, namely observation, interviews, documentation, and triangulation/combination.

\section{RESULTS AND DISCUSSION}

\section{Analysis of the Practice of Converting Agricultural Land to Mining in Pangkalan Jambu District, Merangin Regency, Jambi Province}

The practice of converting agricultural land into mining in Pangkalan Jambu District, Merangin Regency, Jambi Province is carried out in the traditional way or by using heavy equipment. From the data presented in chapter 4 , it can be explained that economically, the conversion of agricultural land to mining is very profitable. On the other hand, the harm caused is greater, such as damage to the environment and agricultural land. Human behavior that has denied its nature as an image of God, Allah SWT, in the end reaps rewards in the form of environmental disasters that occur everywhere. Destruction of forests, damage to the ozone layer, greed in the use of fossil fuels, environmental pollution, and so on. Humans get sanctions that ruin their lives and their lives lead to a terrible gate of destruction. The destruction caused by global warming that triggers climate change, not only causes part of the earth to turn into the sea as experienced by Noah, but also the spread of heat that can scorch living things like reminding humans of the outpouring of fire that destroyed the cities of Sodom and Gomorrah which destroyed the city of Sodom and Gomorrah. leaving only the Prophet Lut and his family.

In the Qur'an and Al-Hadith, the damage caused by human actions, because of greed and greed for nature is abundant. Greed and greed, negates the values of balance in life that depends on the environment. For this reason, protection efforts need to be carried out, in this case efforts to encourage the implementation of the protection of a healthy and good environment are the teachings of Islam contained in the Nash Al-Quran and Hadith which universally provide scientific information that this Nature is the source of life that has been conquered by Allah for the benefit of God. human life as in the Koran (Kotijah, 2011). The damage referred to in Islam is of at least two kinds, the first, the Zhahiriah (material) damage, and the second, the spiritual (spiritual) damage. Not only property will be destroyed, but body and soul can be destroyed. From the concept of Islamic teachings, it is very influential to shape the attitudes and culture of the community to protect and maintain the balance of the ecosystem. The flow of people's thoughts and ideologies that nature and the environment contain sacred and divine values, the Islamic religion adopted by the community believes that Allah SWT sent humans to earth as "Khalifah". When sending humans as caliphs, Allah SWT has given the right of recommendation to utilize Nature by 
submitting Nature and the environment to humans. In its implementation, humans should not cause environmental damage that leads to disaster for humans themselves.

Analysis of the Impact of Conversion of Agricultural Land into Mining on the Community Economy in Pangkalan Jambu District, Merangin Regency, Jambi Province

Work is one of the main factors that cause humans to live a more decent life or not. Where the people who are in Pangkalan Jambu District, Merangin Regency, Jambi Province, the majority are farmers because this village is an area that is quite famous for its agricultural areas. But with the work they do as farmers, they have not been able to fulfill their daily needs. The development of increasing economic needs as it is today can require people to work harder to meet the needs of life both in urban and rural areas, this shows that rural communities who do not have permanent jobs or only depend on agriculture and are also still using manually so that people's economic income is still very slow and people's lives are very squeezed by this kind of situation (Mointi, 2010).

In a job can make in a society there are various layers or social strata. Where the average community in this village is still very simple, considering that many people do not have proper jobs and even many people do not have jobs so that their lives are still very unfortunate. Meanwhile, people who have jobs such as civil servants only reach $3 \%$ so that social strata or strata also occur in this society, people who have jobs such as civil servants or seen from jobs that can generate a lot of money will be respected or become respected people in this sub-district. In these circumstances, people are forced to turn their agricultural land into mining. Although it can increase the economic level, the benefits generated are very large. Therefore, the transfer of land from agricultural functions to mining should be minimized or stopped in order to protect the environment.

Analysis of Islamic Economic Law and Maqashid Syariah on the Conversion of Agricultural Land to Mining in Pangkalan Jambu District, Merangin Regency, Jambi Province

Agricultural land is a natural resource that has a very broad function in meeting various human needs. From an economic perspective, land is the main fixed input for various agricultural and non-agricultural commodity production activities. The amount of land used for each of these production activities is generally a derivative demand from the needs and demands for the commodities produced. Therefore, the development of land requirements for each type of production activity will be determined by the development of the number of 
requests for each commodity. In general, food commodities are less elastic to income than demand for non-agricultural commodities, the consequence is that economic development that leads to an increase in income tends to cause an increase in demand for land for non-agricultural activities at a faster rate than the increase in demand for land for agricultural activities (Hidayat, 2008).

The Islamic economic system is a system that in particular, has values derived from the Qur'an and Sunnah, which are the basis of the Islamic way of life. Always held in the face of the times and changes in society. All problems that develop, including the economy must remain subject to the principles of sharia (Noor, 2013). Based on the view of life, Islam gives birth to basic values in the economy, namely: 1) Justice, by upholding the values of truth, honesty, courage and consistency in truth. 2) Accountability, to prosper the earth and the universe as the duty of a caliph. Every economic actor has a responsibility to behave properly and safely in realizing the benefit. It also has a responsibility to improve the welfare of society in general, not only the welfare of individuals or certain groups. 3) Takaful (social security), the existence of social security in society will encourage the creation of good relations between individuals and society, because Islam not only teaches vertical relationships, but also places these horizontal relationships in a balanced way (Noor, 2013).

Islam has also outlined agricultural policies (as-siyasah az-zira'iyyah), which is a set of state policies aimed at increasing agricultural productivity (alintaj al-zira'iy) and improving the quality of agricultural production. This agricultural policy is broadly pursued by two methods; first, intensification (atta'miq), for example by using chemical pesticides, modern agricultural technology, or superior seeds. This intensification will be fully assisted by the state. The state will give (not lend) its wealth to farmers who can't afford it so that farmers can buy all agricultural facilities and technology to increase agricultural productivity. This is as Caliph Umar bin Khathab once did, who provided agricultural production facilities to Iraqi farmers to manage their agricultural land. Second, extensification (at-tausi'). This was pursued, among others, by implementing Ihya ul Mawat, Tahjir, and Iqtha '(giving land belonging to the state).

The state will also forcibly expropriate agricultural lands that were abandoned by their owners for the past three years giving them to people who are able to manage them. Shaykh Abdurrahman Al-Maliki also emphasized that apart from the intensification and extension above, agricultural policy must also be free from all foreign intervention and domination, especially the domination of imperialist Western countries (Al-Maliki, 2010). Regarding the management of land that is already owned, Islamic Sharia requires land owners, whether owned 
by way of Ihya 'ul Mawat, Tahjir, or owned in other ways, to manage the land so that it is productive. That is, ownership is synonymous with productivity. In principle, to have means to produce (man yamliku yuntiju). So land management is an integral part of land ownership itself. Therefore, Islamic Sharia does not allow people to own land but the land is not productive. Islam stipulates that anyone who abandons his agricultural land for 3 (three) consecutive years, then his ownership rights are invalid

\section{CONCLUSION}

In the process of converting agricultural land to mining in Pangkalan Jambu District, Merangin Regency, Jambi Province, the majority of the people still use manual tools which in this work process absorb more human resources than sophisticated tools considering that this mine only belongs to the community, so to use tools Sophisticated tools cost a lot of money so they still use manual tools. However, some people who own a large area of land use heavy equipment. The conversion of agricultural land to mining in Pangkalan Jambu District, Merangin Regency, Jambi Province has a significant impact on improving the community's economy. However, the impact of environmental damage is much greater. Soil and water sources become damaged and polluted, and agricultural land cannot be as productive as before.

In the study of Islamic economic law and maqashid sharia, the conversion of agricultural land to mining in Pangkalan Jambu District, Merangin Regency, Jambi Province violates the concept of maslahah. The damage caused by mining is far greater than the economic benefits felt by the community. Because the benefits are greater than the benefits, the conversion of land to mining should be minimized or stopped. The problem of environmental damage in mining is actually a human error, due to greed, greed, and not wanting to share (alms), so there needs to be an effort to raise awareness about the meaning of religious devotion which is implemented in the life of society and the state.

\section{REFERENCES}

Abdurrahman Al-Maliki, As-Siyasah Al-Iqtishadiyah Al-Mutsla, Darul kutub, Mesir, 2010, 187

Akhmad, Fauzi, Ekonomi Sumber Daya Alam dan Lingkungan Teori dan Aplikasi, cet. ke-1, (Jakarta: PT Gramedia Pustaka Utama, 2010), 39

Ali Fikri, dalam Mustafa Kamal, Wawasan Islam dan Ekonomi Sebuah Bunga Rampai, Lembaga Penerbit Fakultas Ekonomi Universitas Indonesia, Jakarta, 1997, 112. 
Elias Anton dan Edward E. Elias, Dalam Muslimin H. Kara, Bank Syariah di Indonesia AnalisisKebijakanPemerintah Indonesia Tentang Perbankan Syariah, UII Press, Yogyakarta, 2005, 23. Islam dan Tranformasi Sosial-Ekonomi karya M. Dawam Rahardjo, cetakan pertama, November 1999, 5-6.

Nurmila Mointi, Alih Fungsi Lahan Pertanian, Jurusan Sosiologi Fakultas Ilmu Sosial Universitas Negri Gorontalo, 2010, 15.

Ruslan Abdul Ghofur Noor," Konsep Distribusi dalam Ekonomi Islam dan format keadilan ekonomi di indonesia" ,2013.Yogyakarta: Pustaka Pelajar. Hal 62

Siti Kotijah, Islam dan Lingkungan Hidup Dibidang Pertambangan , Fakultas Hukum Universitas Mulawarman Samarinda Kalimantan Timur, Jurnal Yuridika: Volume 26 No 2, Mei-Agustus 2011, 143.

Supriadi, Hukum Agraria, Jakarta: PT Gramedia Pustaka Utama, 2010), 45.

Syarif Imama Hidyat,2008. “Analisis Konversi Lahan Sawah Di Propinsi Jawa Timur" jurnal: fakultas pertanain UPN “veteran” Jawa Timur 